\title{
EXTRACTION AND CHARACTERIZATION OF IRAQI ARTEMISIA DRACUNCULUS DRIED AERIAL PARTS EXTRACT THOUGH HPLC AND GC-MS ANALYSIS WITH EVALUATION OF ITS ANTITUMOR ACTIVITY AGAINST 7, 12-DIMETHYLBENZE (a) ANTHRACENE INDUCED SKIN CANCER IN MICE
}

\author{
NABAA MOHAMMED IBRAHEM \\ College of Pharmacy, University of Baghdad, Baghdad, Iraq \\ Email: nabaapharm@yahoo.com \\ Received: 31 Dec 2016 Revised and Accepted: 09 Mar 2017
}

\begin{abstract}
Objective: This study focused on the extraction of bioactive constituents in Iraqi cultivated Artemisia dracunculus L dried aerial parts and phytochemical screening with qualitative estimation of three important flavonols (kampferol, quercetin and rutin). The study also included evaluating the antitumor effects (skin cancer) of methanolic extract for this plant.
\end{abstract}

Methods: Extraction of bioactive constituents was carried out according to standard protocols using 85\% methanol. The phytochemical screening has been done using chemical tests and GC/MS with qualitative estimation of three flavonols (kampferol, quercetin and rutin) utilized preparative high-performance liquid chromatography (PHPLC). Skin cancer in mice was induced by using 7, 12-dimethylbenze (a) anthracene to evaluate the antitumor effect of methanolic extract of Artemisia dracunculus when administered orally via intragastric feeding tube. Body weight, tumor volume, tumor burden, percent of tumor incidence and histopathological examination were measured in all tested animals.

Results: Phytochemical screening revealed the presence of glycosides, volatile oils, alkaloids, tannin, terpenoids, phenolic compounds and flavonoids. The preparative high-performance liquid chromatography (PHPLC) analysis indicated that rutin had the highest concentration followed by quercetin while kampferol had the lowest concentration. The methanolic extract of the Artemisia dracunculus significantly reduced the percent of tumor incidence, tumor volume and tumor burden of skin cancer in mice $(\mathrm{p}<0.05)$

Conclusion: Dried aerial parts of Iraqi Artemisia dracunculus contain many bioactive constituents including three flavonoid compounds (quercetin kampferol and rutin) that may be responsible for chemo preventive effect exerting by methanolic extract of Artemisia dracunculus against 7, 12dimethylbenzeanthracine-induced skin cancer in mice.

Keywords: Artemisia dracunculus L, Quercetin, Kampferol, Rutin, Skin cancer

(c) 2017 The Authors. Published by Innovare Academic Sciences Pvt Ltd. This is an open access article under the CC BY license (http://creativecommons.org/licenses/by/4.0/) DOI: http://dx.doi.org/10.22159/ijpps.2017v9i5.16875

\section{INTRODUCTION}

Man ever since his first appearance on earth, has used plant throughout his historical development as a source of medicines. Medicinal plants have formed the basis of the folkloric medicine which was the primary source for new medicines discoveries [1]. Artemisia dracunculus L. (tarragon) is a perennial herb which belongs to Asteraceae family.

It has a long history of use in culinary traditions. It also possesses a wide range of health benefits and has therefore been widely used as an herbal medicine [2]. Additionally, a wider range of secondary metabolites (flavonoids, phenyl-propanoids, coumarins, tannins, essential oil) are reported, determining Artemisia dracunculus (A. dracunculus) biological activities and its potential use as a source of plant-derived pharmaceutical chemical entities and complex extracts [3].

In traditional medicine tarragon is commonly used to improve a malfunctioning digestive system by increasing appetite, to flush toxins from the body, and as a digestive stimulant, especially in cultures with a high consumption of (red) meat [4].

Arabic cultures have used A. dracunculus to treat insomnia and to dull the taste of medicines. Additionally, it has also been used as an anaesthetic for aching teeth, sores, and cuts and has been used widely in central Asia and Russia for the treatment of skin wounds, irritations, allergic rashes, and dermatitis [5]. In the traditional medicine of Azerbaijan tarragon was used as an antiepileptic, laxative, antispasmodic, and carminative remedy (an infusion made from a teaspoon of its twigs was consumed an hour before meals) [6].
Extracts of $A$. dracunculus are stated to possess a wide range of pharmacological properties including antibacterial, antifungal, antiinflammatory, antidiabetic [7, 8], hepatoprotective, anticonvulsant, gastro protective [2], antitumor and cytotoxic activities [9, 10].

Plants are an important source of potentially useful compounds for the development of new chemotherapeutic agents. In vitro evaluation of plants for the antimicrobial property is the first step towards achieving the aim for developing eco-friendly management of infectious diseases of humans by searching for new biomolecules of plant origin [11].

Hence, the present research was carried out to evaluate the phytochemical compounds of $A$. dracunculus by chemical tests and Gas Chromatography-Mass Spectrometry analysis (GC-MS) and to identify the presence of some flavonol (kampferol, rutin and quercetin) by PHPLC. In addition to that, the study investigated the chemopreventive effect of $A$. dracunculus extract in vivo against 7 , 12-dimethylbenzeanthracine (7,12-DMBA)-induced skin cancer in mice by measuring tumor incidence, tumor volume, tumor burden and examination the pathological changes in skin specimen of tested mice.

\section{MATERIALS AND METHODS}

\section{Plants collection}

The aerial parts of the A.dracunculus were collected from Sulaymaniyah, a city in the north of Iraq, 400 kilometres north of Baghdad. The plant was authenticated at the department of pharmacognosy, college of pharmacy, University of Baghdad. 


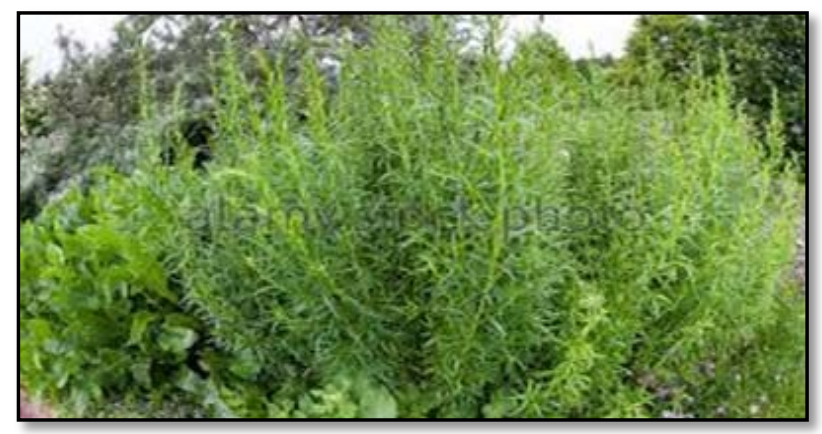

Fig. 1: Artemisia dracunculus (tarragon)

\section{Preparation of plant extract of Artemisia dracunculus}

The whole aerial parts of $A$. dracunculus were washed to be free of extraneous material, dried in the shade for one week at room temperature until dryness. After dryness, the parts have been grinding to the powder by using an electrical blender and then weighed for the extraction procedure. $100 \mathrm{~g}$ of dried powder of aerial parts of $A$. dracunculus were extracted by using soxhlet apparatus in which powdered plant was packed in a thimble of it and extracted with methanol $85 \%$ for $24 \mathrm{~h}$ to extract all possible constituents then filter by using Whatman no.1 filter paper and then cool, and allow to evaporate the solvent using rotary evaporator (Buchi, Germany)at temperature not exceeding $40{ }^{\circ} \mathrm{C}$, the residue dried extract was weighed and subjected for different phytochemical screening $[12,13]$.

\section{Phytochemical screening of methanolic extracts of Artemisia} dracunculus (MEAD)

\section{Phytochemical screening by chemical tests}

The presence of volatile oils, glycosides, alkaloids, terpenoids, tannin, saponins, phenolic compounds and flavonoids had been identified by doing the general test as a preliminary phytochemical screening of $A$. dracunculus dried aerial parts extract [14-16].

\section{GC-MS analysis}

Preparation of sample for GC-MS: $0.25 \mathrm{~g}$ of the MEAD was dissolved in $85 \%$ methanol. The extract was filtered through microfilter $0.45 \mu \mathrm{m}$, and then $2 \mu \mathrm{l}$ of this solution was employed for GC/MS screening [17, 81].

GC-MS screening: GC-MS screening was carried out on a Shimadzu GCMS-QP 2010 Ultra system comprising a gas chromatograph interfaced to a mass spectrometer (GC-MS) instrument employing the following conditions: column VF-5MS fussed silica capillary column $(30.0 \mathrm{~m} \times 0.25 \mathrm{~mm} \times 0.25 \mu \mathrm{m}$, composed of $5 \%$ phenyl $/ 95 \%$ dimethyl polysiloxane), operating in electron impact mode at $70 \mathrm{ev;}$ helium $(99.999 \%)$ was used as carrier gas at a constant flow of 1 . $\mathrm{ml} / \mathrm{min}$ and an injection volume of $0.5 \mu \mathrm{l}$ were employed (split ratio of $10: 1$ ) injector temperature $240{ }^{\circ} \mathrm{C}$ ion source temperature $200{ }^{\circ} \mathrm{C}$. The oven temperature was programmed from $100{ }^{\circ} \mathrm{C}$ (isothermal for $3 \mathrm{~min}$ ) with an increase of $10{ }^{\circ} \mathrm{C} / \mathrm{min}$, to $240{ }^{\circ} \mathrm{C}$ ending with a $9 \mathrm{~min}$ isothermal at $270{ }^{\circ} \mathrm{C}$. Mass spectra were taken at $70 \mathrm{ev}$; a scan interval of $0.5 \mathrm{~s}$ and fragments from 40 to $440 \mathrm{Da}$. Total GC running time is $30 \mathrm{~min}[17,18]$.

\section{Phytochemical screening of some flavonoids by preparative} high-performance liquid chromatography (PHPLC)

One of the most important groups of biologically active secondary metabolites in $A$. dracunculus are flavonoids, which act as (antimicrobial, anti-allergic, anti-inflammatory, antioxidant and anticancer). Among different classes of flavonoid, flavonol class is the most important and widely spread flavonoid, in which quercetin, kampferol, and Rutin are the best examples and the most potent flavonol class $[19,20]$. So that we analyzed the MEAD for the determination (qualitative assay) of them by using SHIMADZU LC2010 AHT preparative high-performance liquid chromatography at which identical chromatographic condition, identification was done by comparison the retention time of plant extract and authenticated flavonol standard [21].

Table 1: Standard conditions of PHPLC

\begin{tabular}{ll}
\hline HPLC parameters & HPLC conditions \\
\hline Mobile phase & acetonitrile: water: acetic acid $(60: 40: 0.5)$ \\
Column & Phenomenex $\mathrm{C}_{18} 250 \mathrm{X} 4.6 \mathrm{~mm}, 5 \mu \mathrm{m}$ particle size \\
Temperature & Room temperature \\
Flow rate & $10 \mathrm{ml} / \mathrm{min}$ \\
Injection volume & $2 \mathrm{ml}$ \\
Detection & UV-Visible detector at $\lambda=254 \mathrm{~nm}$ \\
\hline
\end{tabular}

Effect of MEAD on prevention of 7, 12-dimethyl benzanthracene induced skin cancer in mice

\section{Drugs and chemicals}

7, 12-dimethylbenzeanthracine (DMBA) was purchased from Sigma-Aldrich. Acetone, Formalin and methanol were purchased from (Sigma-Aldrich). While other chemicals available commercially. The solution of DMBA was prepared by dissolving $25 \mu \mathrm{g}$ of DMBA in $1 \mathrm{ml}$ which represent the dose for each mouse [22].

\section{Preparation of oral dose}

The dry extracts of $A$. dracunculus were triturated in mortar and pestle and suspended in purified water and make it in the concentration of $10 \mathrm{mg}$ of extract $/ 1 \mathrm{ml}$. The dose that has been given to the mice was $500 \mathrm{mg} / \mathrm{kg} / \mathrm{d}$ [23]

\section{Animals}

Eighteen balb/c adult male mice were purchased from the High institute for infertility Diagnosis and assisted Reproductive Technology, Baghdad, Iraq. They were maintained in the animal house at the college of veterinary medicine-University of Baghdad.
All mice were randomly assigned into 3 groups (six mice/group) in isolated plastic cages and allowed to feed on pellet diet and water ad libitum under a standard condition of $12 \mathrm{~h}$ light and $12 \mathrm{~h}$ dark at $25^{\circ} \mathrm{C}$. The experiment described here was approved by the Institutional Review Board (IRB)/Ethical committee (EC) of College of pharmacy/ University of Baghdad, Iraq (Proposal No. 372: dated. 25-01-2016).

\section{Experimental design}

A total of six mice were randomly allocated into each of three groups (Group A, B and C). According to the Azuine and Bhide procedure, skin cancer was developed in mice [24]. Group A (positive control group) and Group B (Artemisia extract treated group) were treated with topical DMBA $(25 \mu \mathrm{g} / \mathrm{ml})$ dissolved in acetone twice weekly (on dorsal shaved region) for $8 \mathrm{w}$ as an inducer for skin cancer. Group B was also orally treated with Artemisia extract in a dose $(200 \mathrm{mg} / \mathrm{kg}) 3$ times weekly by gastric lavage starting one week before application of DMBA and continue through the experiment for $13 \mathrm{w}$. Group C (negative control group) received only acetone topically for $8 \mathrm{w}$ on dorsal shaved region twice weekly. At the end of the experiment, all the mice are sacrificed by cervical dislocation followed by the skin histo- 
pathological analysis. The body weight of each mouse was measured weekly during the experimental period.

The tumor number was counted and volume for each one (per each mouse) was measured by an external caliper that used to measure the length, width and height of the tumor and put it in the following equation.

$$
V=\left(\frac{4}{3}\right) \pi\left[\frac{D 1}{2}\right]\left[\frac{D 2}{2}\right]\left[\frac{D 3}{2}\right]
$$

D1, D2 and D3 represent tumors diameter in millimetre ( $\mathrm{mm})$. The tumor burden has been calculated also, by multiplying tumor volume and number of tumors/mice.

\section{Histopathology examination}

After its removal, the skin specimen is placed in a container with $10 \%$ formalin to preserve it and put labelled on each container indicate the group name. Next, samples sent to the pathological lab. To be examined by a pathologist. The pathological diagnosis included cross-examination (calculation the number of tumors in each specimen and measurement the three dimensions of each tumor. After that, microscopically examinations were done by selecting a large tumor sample and putting in a series of alcohol grades, and blocks were prepared by embedding in paraffin wax. Then slides were prepared by cutting 5 - $\mu$ m-thick sections, stained with hematoxylin and eosin, and looked by the pathologist under a light microscope [25].

\section{Statistical analysis}

The data collected about body weight, tumor incidence, tumor volume and tumor burden were analyzed using available computer facilities of SPSS-17 and Microsoft Excel 2007.

The following measurement and tests were used: 1 . Mean and standard deviation (SD). 2. ANOVA (analysis of variance) test (oneway test) was used to test the significance of differences among the result of more than two groups.

An association or difference was considered statistically significant if the probability value (P-value) was less or equal to 0.05 and highly significant if the probability value (P-value) was less or equal to 0.001 .

\section{RESULTS}

Methanolic extract was obtained from the experimental work, in which the methanolic extract has extracted by Soxhlet apparatus for $24 \mathrm{~h}$ :

\section{Phytochemical screening by chemical tests}

Results of preliminary chemical screening tests shown in table 3 indicate the presence of glycosides, volatile oils, saponins, alkaloids, terpenoids, tannin, phenolic compounds and flavonoids in methanolic extract of Iraqi A. dracunculus dried aerial parts.

Table 2: The preliminary result of chemical screening tests for Artemisia dracunculus

\begin{tabular}{ll}
\hline Phytochemicals & Results \\
\hline Alkaloids & Present \\
Flavonoids & Present \\
Tannins and phenolic compounds & Present \\
Volatile oils & Present \\
Terpenoids & Present \\
Saponins & Present \\
Glycosides & Present \\
\hline
\end{tabular}

\section{Phytochemical screening by GC-MS}

Artemisia dracunculus dried aerial parts extract showed the presence of medicinal active constituents (table 3). In the GC-MS analysis, 93 bioactive phytochemical compounds were identified in the methanolic extract of $A$. dracunculus. Identification of phytochemical compounds is based on peak area, molecular weight and molecular formula, some of the GC-MS peaks remained unidentified, because of the absence of authentic samples and library data of corresponding compounds.

Table 3: Identification of some components in the methanolic extracts of the Artemisia dracunculus with their molecular formula, molecular weight, nature and biological activity

\begin{tabular}{|c|c|c|c|c|c|}
\hline Compound name & $\begin{array}{l}\text { RT } \\
\text { min }\end{array}$ & $\begin{array}{l}\text { Peak } \\
\text { area\% }\end{array}$ & $\begin{array}{l}\text { Molecular } \\
\text { formula }\end{array}$ & $\begin{array}{l}\text { Molecular } \\
\text { weight }\end{array}$ & Nature and biological activity \\
\hline $\begin{array}{l}\text { Thiophene-2-acetic acid, dodec-9-ynyl } \\
\text { ester }\end{array}$ & 11.958 & 0.47 & $\mathrm{C}_{18} \mathrm{H}_{26} \mathrm{O}_{2} \mathrm{~S}$ & 306 & $\begin{array}{l}\text { Thiophene } \\
\text { Has very strong anti-fungal activity }\end{array}$ \\
\hline phytol & 18.713 & 0.68 & $\mathrm{C}_{20} \mathrm{H}_{40} \mathrm{O}$ & 296 & $\begin{array}{l}\text { Phytol can be used as a precursor for the } \\
\text { synthesis of vitamin E and vitamin K1. }\end{array}$ \\
\hline $\begin{array}{l}\text {-1,2,4-Oxadiazole, 5-methyl-3-(1- } \\
\text { piperidylmethyl) }\end{array}$ & 16.683 & 0.14 & $\mathrm{C}_{9} \mathrm{H}_{15} \mathrm{~N}_{3} \mathrm{O}$ & 181 & $\begin{array}{l}\text { Piperidine alkaloids, anti-inflammatory, anti- } \\
\text { oxidant }\end{array}$ \\
\hline $\begin{array}{l}\text { Benzoic acid, hydroxy-3-(4-methoxy-2- } \\
\text { methyl-4-oxobutanoyl)-6-methyl-, } \\
\text { methyl ester }\end{array}$ & 20.575 & 1.12 & $\mathrm{C}_{15} \mathrm{H}_{18} \mathrm{O}_{6}$ & 294 & $\begin{array}{l}\text { Phenolic compound, very strong anti-oxidant, } \\
\text { anti-bacterial agent }\end{array}$ \\
\hline $\begin{array}{l}\text { 1-(2-Ethyl-[1,3]dithian-2-yl)-3-methyl- } \\
\text { butan-1-ol }\end{array}$ & 21.067 & 0.05 & $\mathrm{C}_{11} \mathrm{H}_{22} \mathrm{OS}_{2}$ & 234 & $\begin{array}{l}\text { Thiophene } \\
\text { Very strong anti-fungal }\end{array}$ \\
\hline Bicyclo [3.3.1]non-2-en-9-ol & 22.017 & 0.3 & $\mathrm{C}_{9} \mathrm{H}_{14} \mathrm{O}$ & 138 & $\begin{array}{l}\text { Bicyclic-alcohol volatile oil, anti-septic, } \\
\text { carminative agent }\end{array}$ \\
\hline 6-Methoxy-2-aminopyridinamine & 23.117 & 0.07 & $\mathrm{C}_{6} \mathrm{H}_{8} \mathrm{~N}_{2} \mathrm{O}$ & 124 & $\begin{array}{l}\text { Piperidine alkaloids, anti-inflammatory, anti- } \\
\text { oxidant }\end{array}$ \\
\hline Hexadecanoic acid, methyl ester & 19.151 & 21.32 & $\mathrm{C}_{17} \mathrm{H}_{34} \mathrm{O}_{2}$ & 270 & $\begin{array}{l}\text { Fatty acid, Hexadecanoic acid is used to } \\
\text { produce soaps, cosmetics, also as a long-acting } \\
\text { release carrier for drug delivery. }\end{array}$ \\
\hline
\end{tabular}




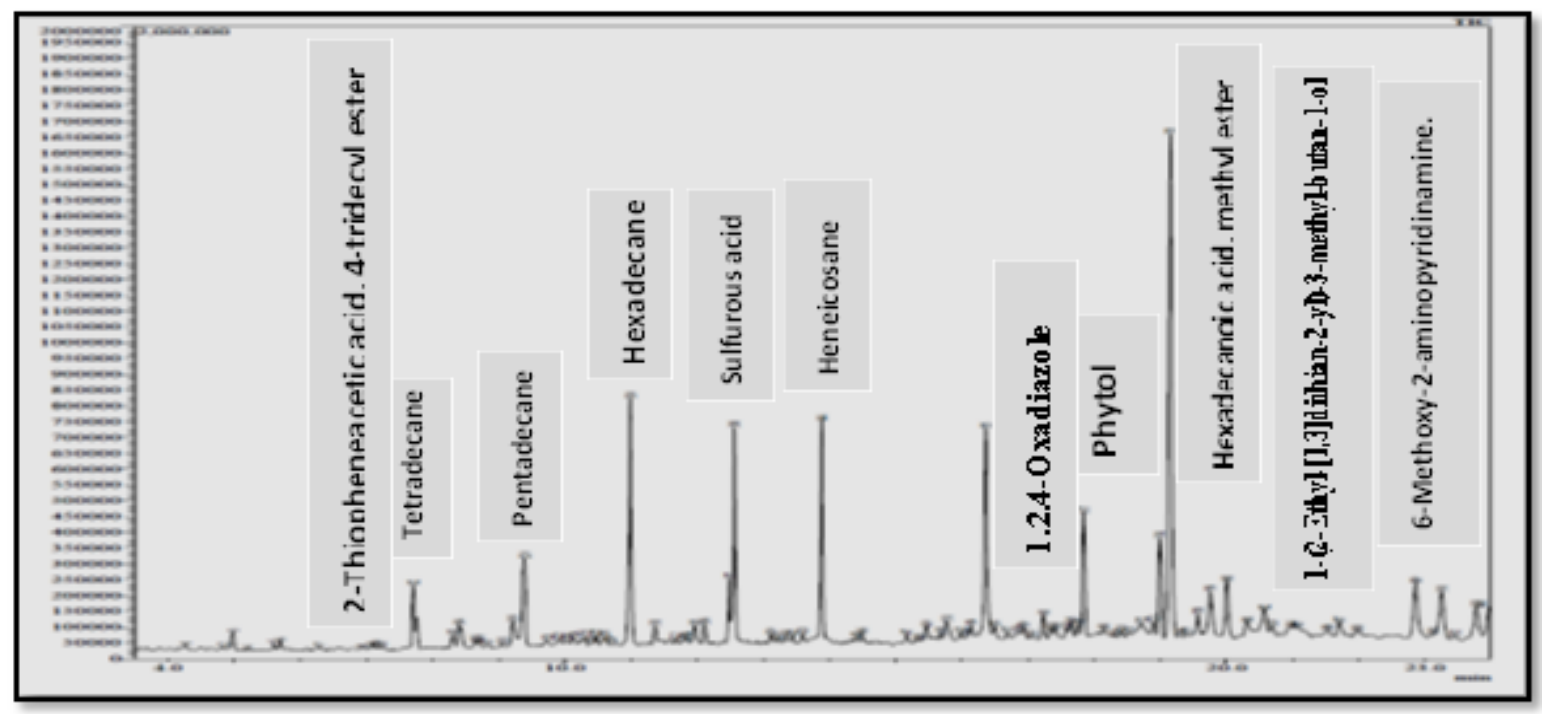

Fig. 2: GC-MS Chromatogram of Artemisia d. dried aerial parts

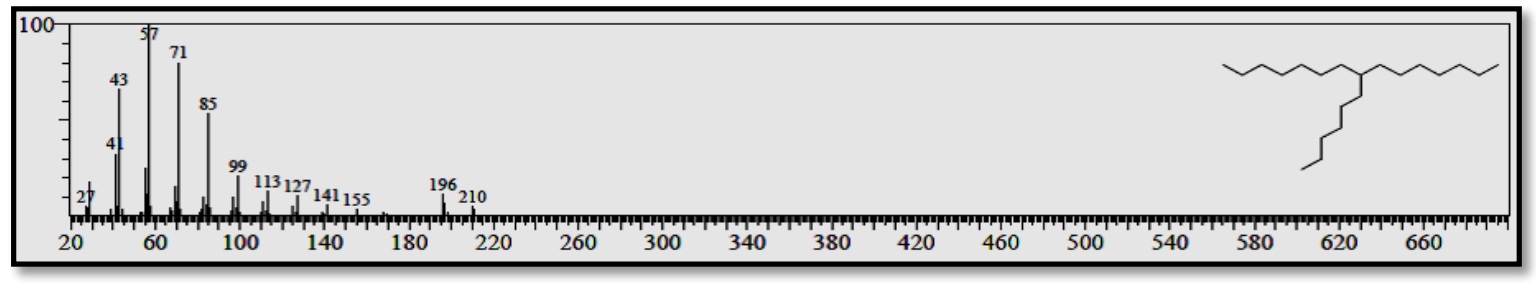

Fig. 3: GC-MS spectrum of thiophene-2-acetic acid, dodec-9-ynyl ester

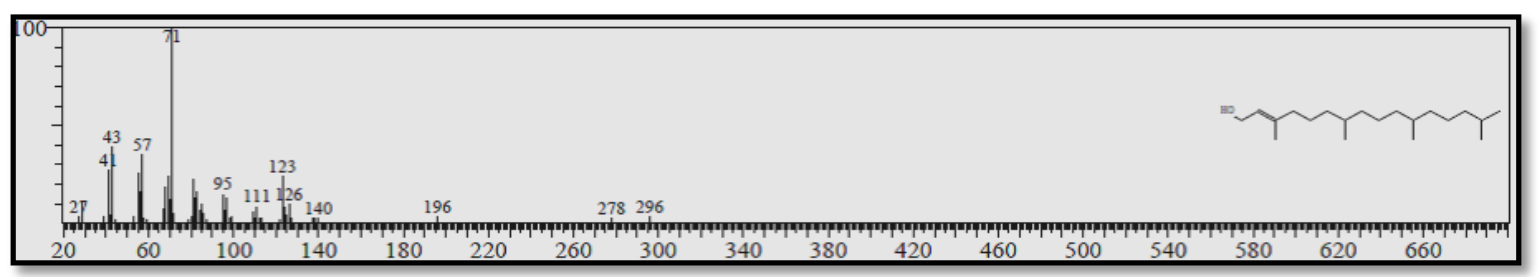

Fig. 4: GC-MS spectrum of phytol

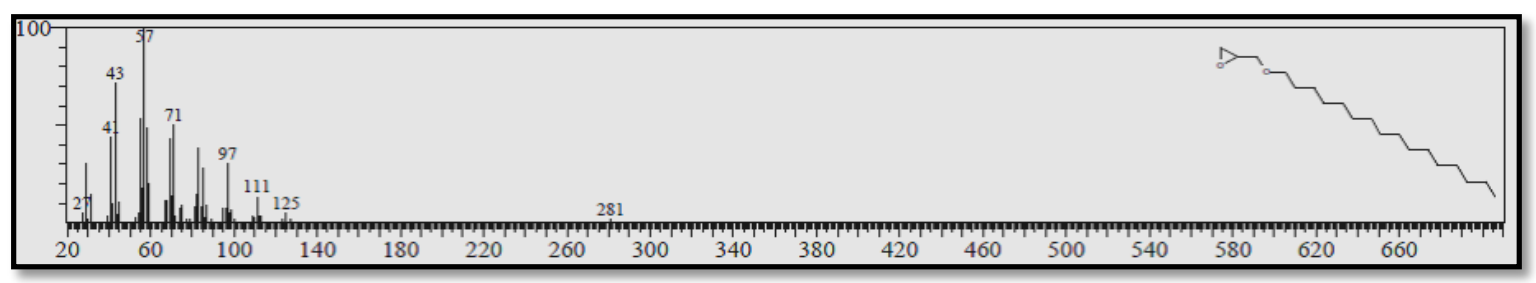

Fig. 5: GC-MS spectrum of 1,2,4-0xadiazole, 5-methyl-3-(1-piperidylmethyl)

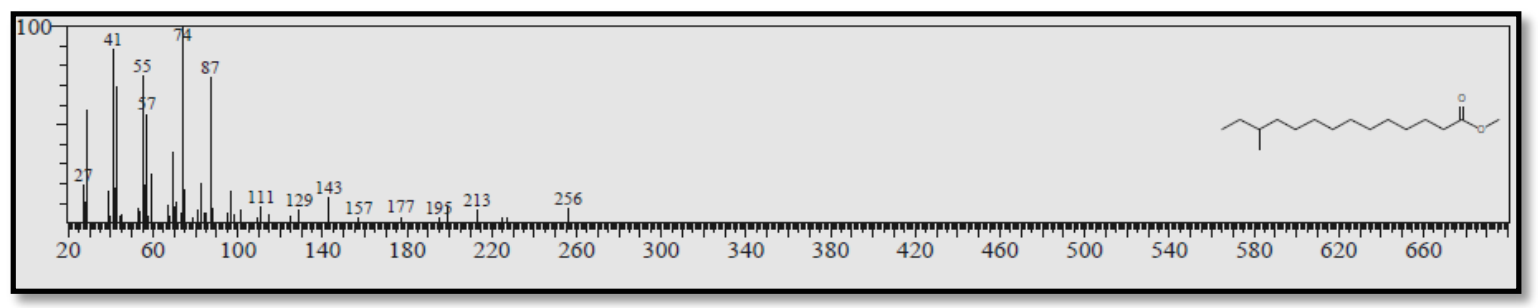

Fig. 6: GC-MS spectrum of1-(2-Ethyl-[1,3]dithian-2-yl)-3-methyl-butan-1-ol 


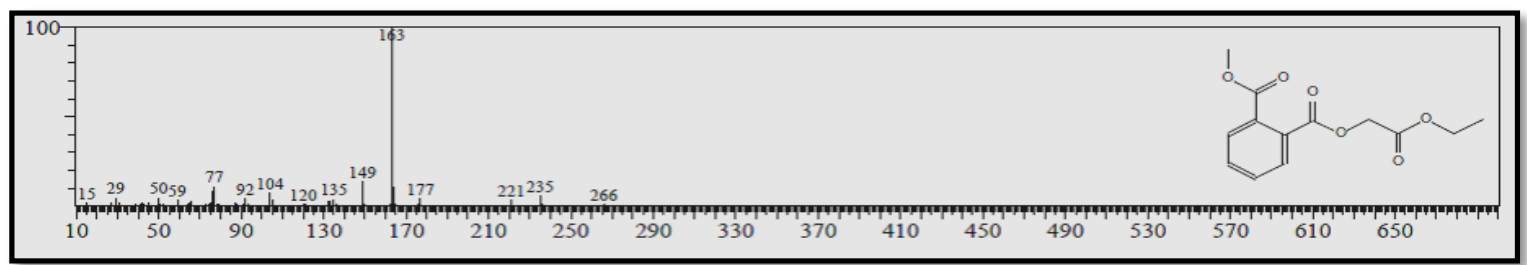

Fig. 7: GC-MS spectrum of bicyclo [3.3.1]non-2-en-9-ol

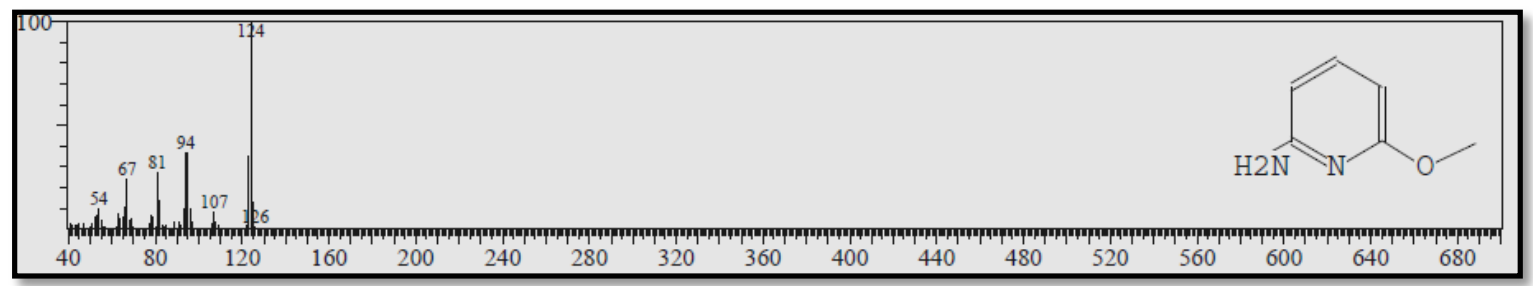

Fig. 8: GC-MS spectrumof 6-methoxy-2-aminopyridinamine

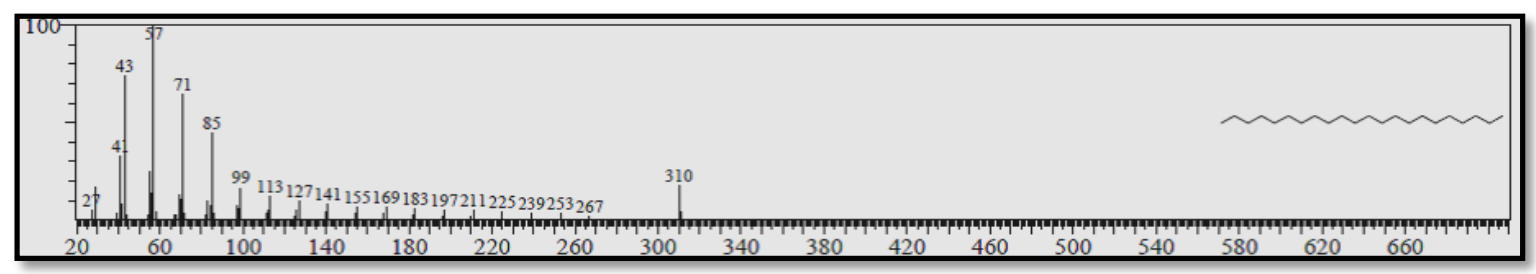

Fig. 9: GC-MS spectrum of hexadecanoic acid

Phytochemical screening of some flavonoids by PHPLC

The result reveals that PHPLC method was efficient for qualitative estimation of some flavonoids (quercetin, kampferol, rutin) in Iraqi $A$. dracunculus dried aerial parts extract, in which both of flavonol standards and methanolic extract retention time were identical as shown in fig. 10, $11,12,13$ and illustrated in table 4.

Table 4: Retention time of quercetin, kampferol, rutin and their standards in sample extract using PHPLC

\begin{tabular}{lll}
\hline Flavonols & $\mathbf{R}_{\mathbf{t}}$ value of standard (min. & $\mathbf{R}_{\mathbf{t}}$ value of flavonol in methanolic extract \\
\hline Quercetin & 5.525 & 5.500 \\
Kampferol & 5.825 & 5.983 \\
Rutin & 3.300 & 3.142 \\
\hline
\end{tabular}

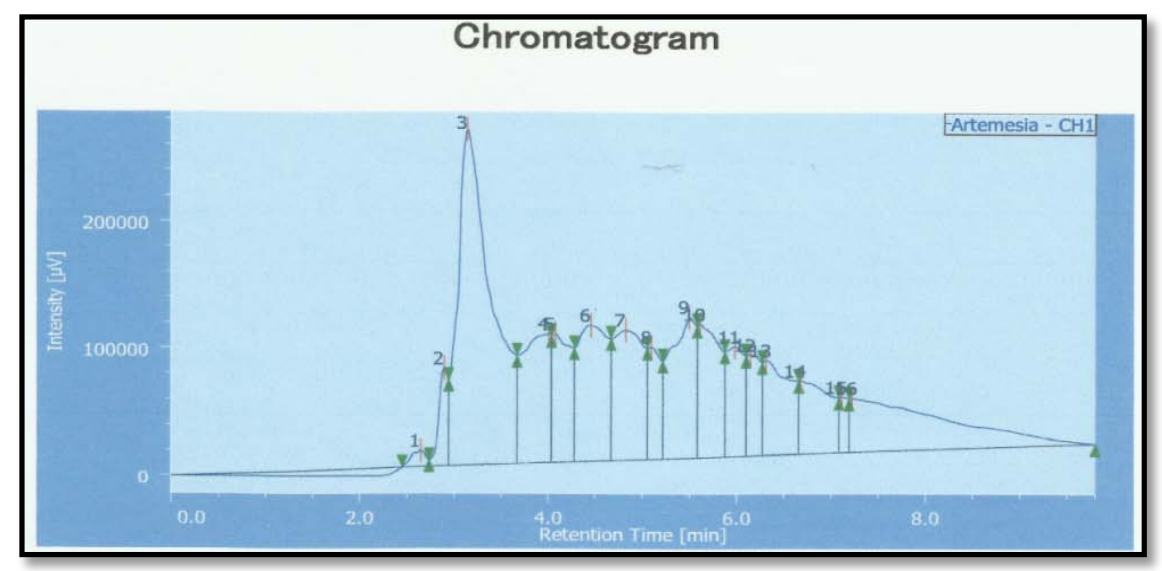

Fig. 10: PHPLC chromatogram of methanolic Artimisia aerial parts extract 


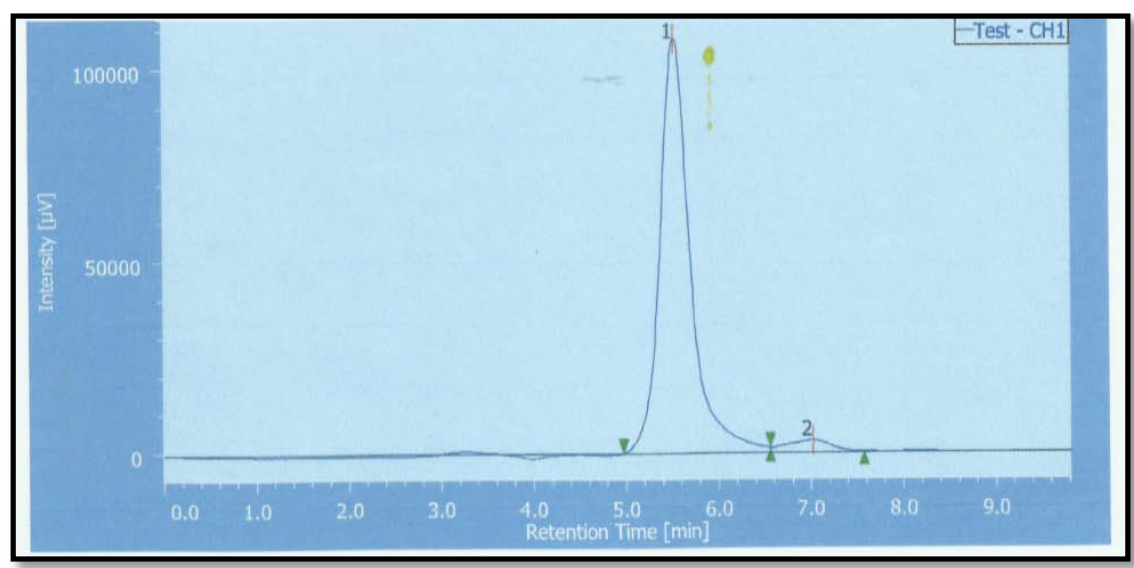

Fig.11: PHPLC chromatogram of std. quercetin

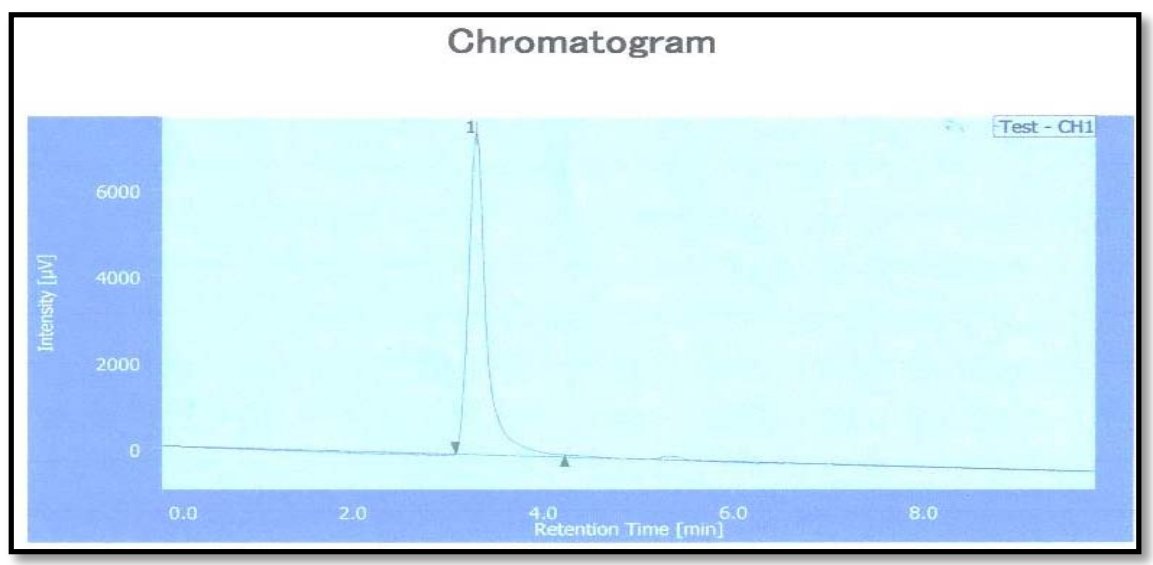

Fig. 12: PHPLC chromatogram of std. rutin

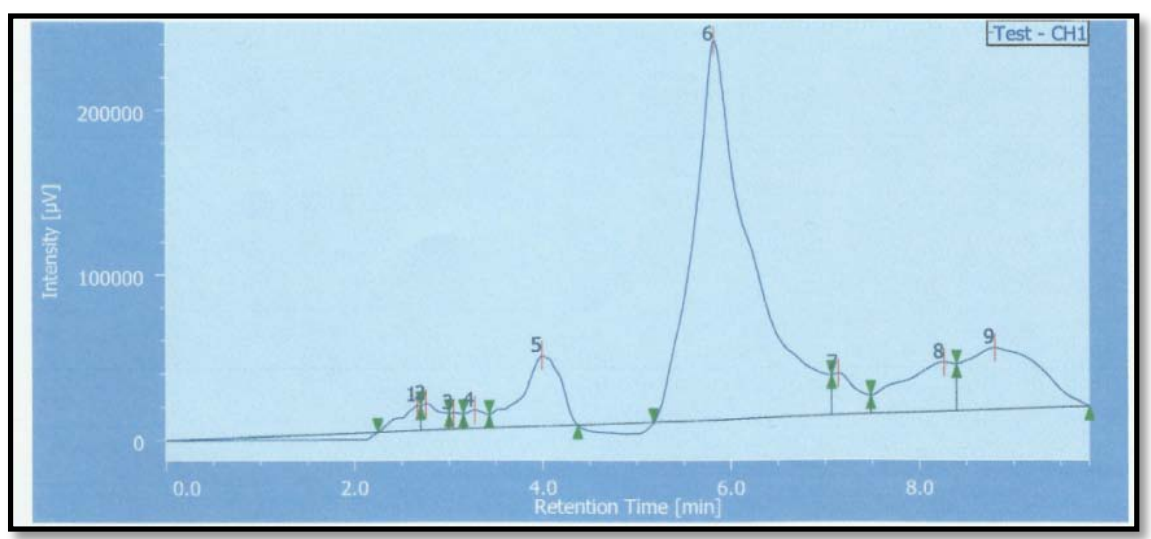

Fig.13: PHPLC chromatogram std. kampferol

Effect of methanolic extract of Artemisia dracunculus on prevention of 7,12 -dimethyl benzanthracene induced skin cancer in mice

The preventive effect of methanolic extract of Artemisia against skin tumor has performed in this study using animal model for induction of skin cancer by DMBA carcinogens.

\section{Body weight}

All of the mice were weighed at the first of the experiment, then the body weight for each mouse in each group was measured weekly and the average weight was calculated and analyzed statistically. The statistical analysis demonstrated no changes in the initial average body weight between the 3 groups $(p>0.05)$ with a gradual increase in the mean body weight during the experiment, as shown in table (6) However, at the end of the research, the mean body weight of the positive control group was reduced with significant differences from negative control and Artemisia extract treating group $(\mathrm{p}<0.05)$.

\section{Tumor incidence}

Percentage of tumor incidence was calculated as the ratio of a number of tumor-bearing mice in a group/number of mice in a group $\times 100$. Fig. (15) Demonstrates that there is a highly significant 
difference in the percent of tumor incidence between 3 groups. The percent of tumor incidence in the positive control group was $100 \%$ because all the mice developed tumor after $8 \mathrm{w}$ (fig. $14 \mathrm{~A}$ ). While in Artemisia treated group, only one mouse developed a tumor (16.7\%) and not seen in other mice (fig. 14 B). Treatment the mice in group B with Artemisia extract that significantly reduced tumor expansion (volume) and tumor burden when compared with those mice in group A that exposed to DMBA only (table 5).

\section{Treatment with metformin inhibits polyp formation}

To investigate the effect of metformin in polyp formation, we treated mice with metformin for $32 \mathrm{wk}$ (from 7 to $39 \mathrm{wk}$ of age). Treatment with metformin significantly inhibited polyp formation (number) and polyp expansion (size) in mice (table 2). Larger polyps, particularly those $>3 \mathrm{~mm}$ in diameter, were not found among the metformin-treated mice (fig. 3).

All the animals survived the experimental period and remained in good health, with no clinical signs of nutritional fleiency. At the end of the experiment, the average body weight of the animals did not differ statistically between the experimental groups (fig. 2B).

\section{Treatment with metformin inhibits polyp formation}

To investigate the effect of metformin in polyp formation, we treated mice with metformin for $32 \mathrm{wk}$ (from 7 to $39 \mathrm{wk}$ of age).

Treatment with metformin significantly inhibited polyp formation (number) and polyp expansion (size) in mice (table 2). Larger polyps, particularly those $>3 \mathrm{~mm}$ in diameter, were not found among the metformin-treated mice (fig. 3). All the animals survived the experimental period and remained in good health, with no clinical signs of nutritional dficiency. At the end of the experiment, the average body weight of the animals did not differ statistically between the experimental groups (fig. 2B).

\section{Treatment with metformin inhibits polyp formation}

To investigate the effect of metformin in polyp formation, we treated mice with metformin for $32 \mathrm{wk}$ (from 7 to $39 \mathrm{wk}$ of age). Treatment with metformin significantly inhibited polyp formation (number) and polyp expansion (size) in mice (table 2). Larger polyps, particularly those $>3 \mathrm{~mm}$ in diameter, were not found among the metformin-treated mice (fig. 3).

All the animals survived the experimental period and remained in good health, with no clinical signs of nutritional fleiency. At the end of the experiment, the average body weight of the animals did not differ statistically between the experimental groups (fig. 2B).

\section{Treatment with metformin inhibits polyp formation}

To investigate the effect of metformin in polyp formation, we treated mice with metformin for $32 \mathrm{wk}$ (from 7 to $39 \mathrm{wk}$ of age). Treatment with metformin significantly inhibited polyp formation (number) and polyp expansion (size) in mice (table 2). Larger polyps, particularly those $>3 \mathrm{~mm}$ in diameter, were not found among the metformin-treated mice (fig. 3). All the animals survived the experimental period and remained in good health, with no clinical signs of nutritional dficiency. At the end of the experiment, the average body weight of the animals did not differ statistically between the experimental groups (fig. 2B).

Table 5: Effect of methanolic extract of Artemisia on the body weight, tumor volume and tumor burden in DMBA treated mice

\begin{tabular}{|c|c|c|c|c|}
\hline \multirow[t]{2}{*}{ Groups } & \multicolumn{2}{|c|}{ Body weight (g) } & \multirow[t]{2}{*}{ Tumor volume (mm) } & \multirow[t]{2}{*}{ Tumor burden } \\
\hline & Initial & Final & & \\
\hline Group A (DMBA treated group) & $17.91 \pm 2.28^{\mathrm{a}}$ & $28.16 \pm 2.48^{\mathrm{a}}$ & $40.8568 \pm 22.24^{a}$ & $4.00 \pm 2.366^{\mathrm{a}}$ \\
\hline Group B (Artemisia extract+DMBA treating group) & $17.25 \pm 2.13^{\mathrm{a}}$ & $34.66 \pm 1.5^{b}$ & $6.2857 \pm 15.39^{b}$ & $0.1667 \pm 0.408^{b}$ \\
\hline Group C (Negative control group) & $16.66 \pm 2.09^{a}$ & $34.50 \pm 3.82^{\mathbf{b}}$ & $0.0000 \pm 00.00^{\mathbf{b}}$ & $0.000 \pm 00^{\mathbf{b}}$ \\
\hline
\end{tabular}

Data are presented as mean \pm SD $(n=6)$. Statistical comparison: Positive control groups (DMBA alone) versus Artmemisia extract treating group and negative control group. The superscript "a" and "b" denotes statistical significance. For example, if groups A, B and C have "a" it means there is no statistical significance between them at $p<0.05$. While, if the group A has "a" and either group B or C has denoted " $b$ " it means there is statistical significance between them at $\mathrm{p}<0.05$.
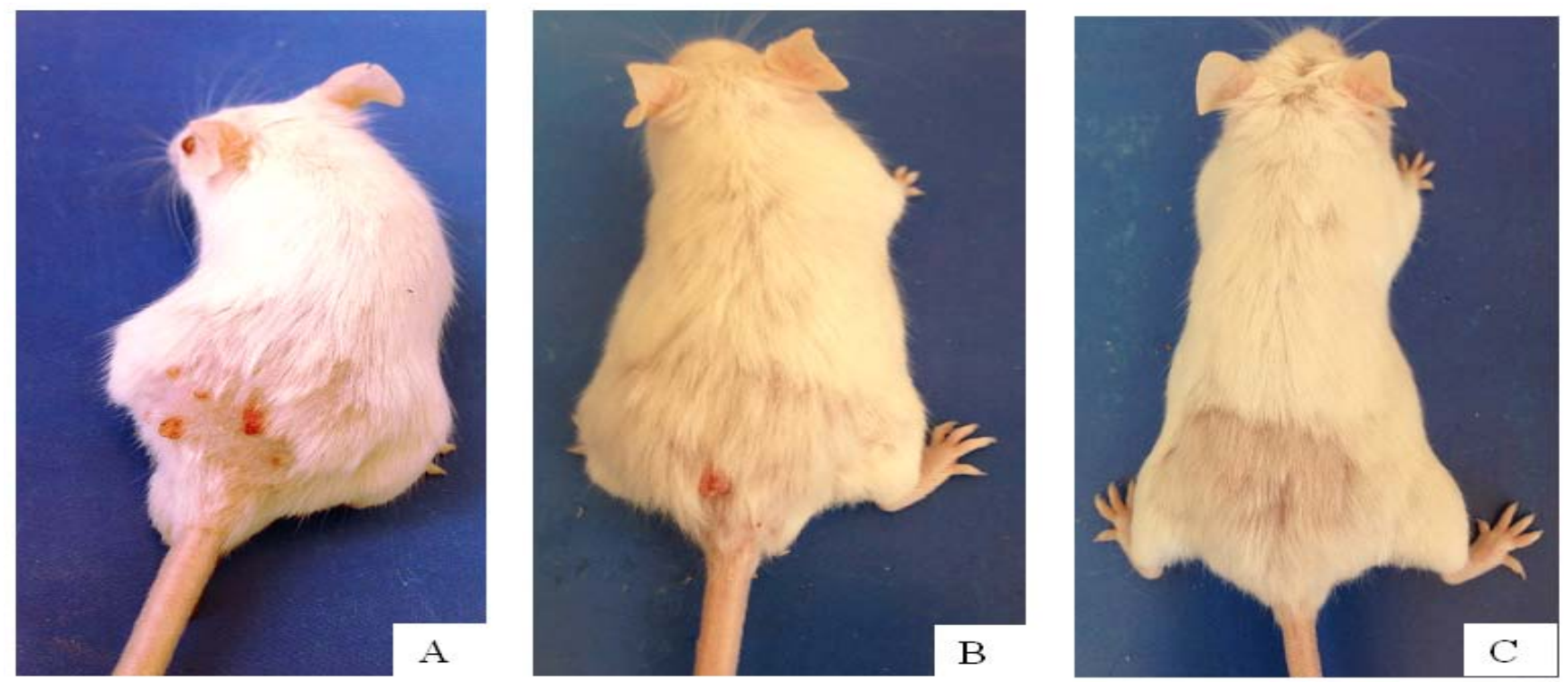

Fig. 14: Representative images for an animal from positive control group (A) and Artemisia extract administered group (B) and Negative control group (C), taken at the end of the experiment 


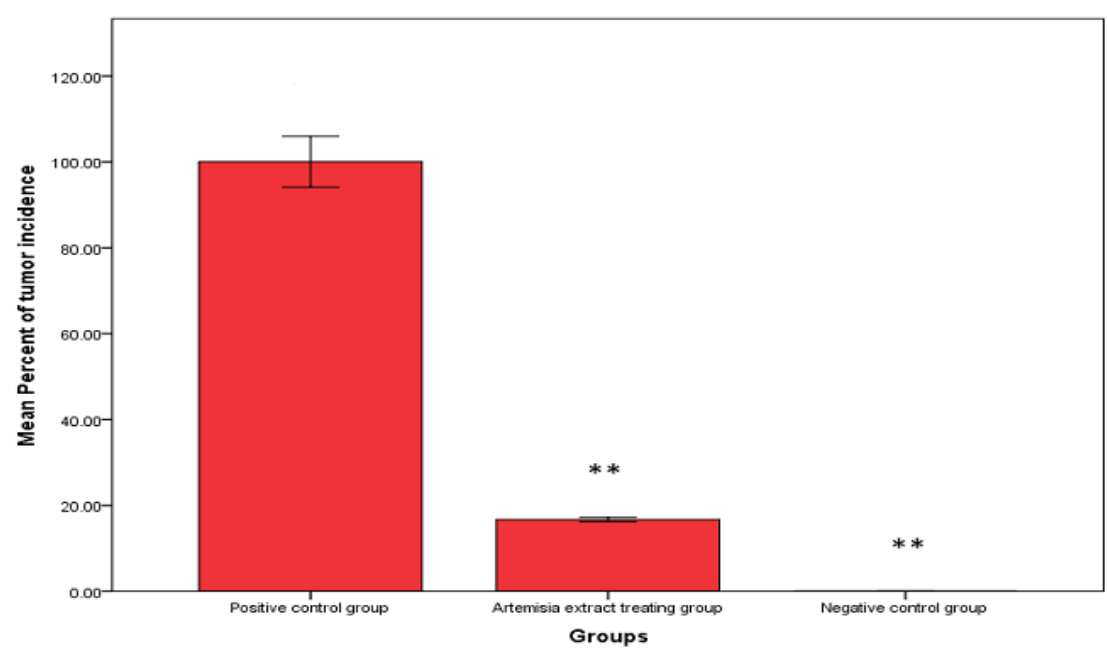

Fig. 15: Percent of tumor incidence in the three experimental animal groups. Values are expressed as mean $\pm \mathrm{SD}(\mathrm{n}=6)$ ) The comparison is made as a positive control group (DMBA alone) versus Artemisia extract treating group (Artemisia extract+DMBA) and Negative control group. Statistical significance: $* * P<0.001$

\section{Histopathology}
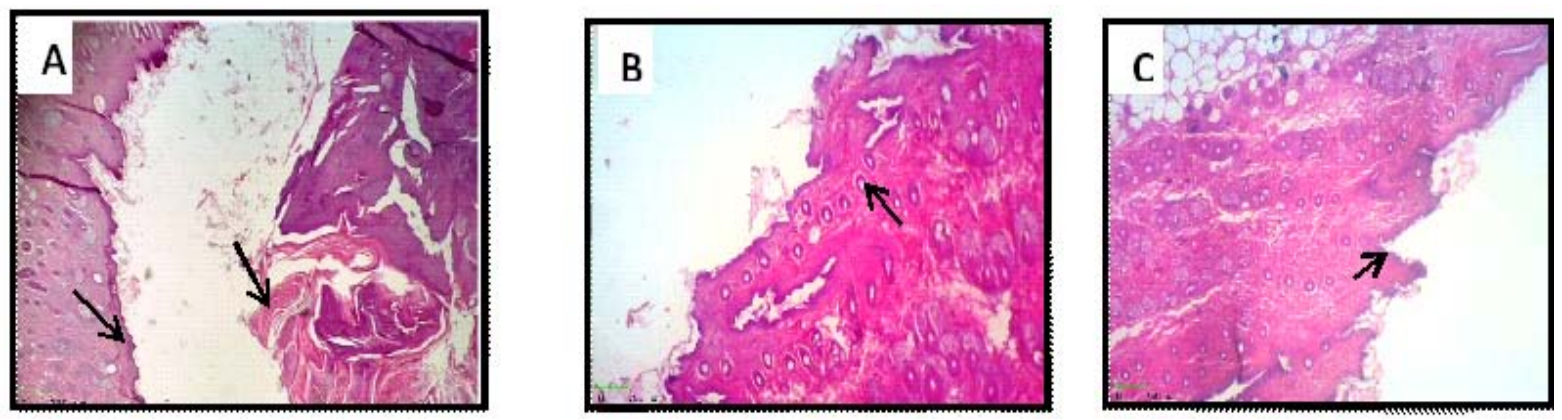

Fig. 16: Histopathology observation in skin tissue of experimental animal for the positive control group (A); Artemisia extract treating group (B) and negative control group (C) represented by $\mathrm{H}$ and $\mathrm{E}$ staining. Microscopic image for group A showing well differentiated squamous cell carcinoma and thicken of the epidermis (arrow). Microscopic image for group C and B showing normal anatomy for skin with epidermis and hair follicles (arrow) (magnification $10 \mathrm{X}$ )

Histopathological results demonstrated that skin tissue specimen for positive control group exhibited squamous cell carcinoma with sever hyperplasia, thickening and proliferation of epidermis (hyperkeratosis) and clear morphological alteration in skin tissue comparing to normal epithelium, epidermis and hair follicles seen in negative control group (fig. $16 \mathrm{~A}$ and C). The mild proliferation of epidermis with normal epithelium and hair follicles has seen in Artemisia extract treating group. (fig. 16 B)

The experiment shows a significant reduction in skin tumor volume caused by those groups of mice treated by the methanolic extract of Artemisia, comparing with positive control and negative control group.

\section{DISCUSSION}

Artemisia dracunculus has been widely used in traditional medicine, and a large number of researchers confirm this species' has a beneficial pharmacological activity like hepatoprotective effect, antiinflammatory activity, anti-hyperglycemic action, anti-hyperlipidemia action, antibacterial, antifungal, antioxidant activity, neurotrophic activity, anticancer activity and in the treatment of sickle cell anemia [26-30].

Results of this study show that the methanolic extract of Iraqi $A$. dracunculus dried aerial parts contains glycosides, volatile oils, saponnin, alkaloids, terpenoids, tannin, phenolic compounds and flavonoids. Several pieces of evidence from many studies documented that the flavonoid compounds (rutin, quercetin and kaempferol) that have been screened in this study has a potential chemo preventive effect against carcinogen-induced skin cancer in mice. Rutin has showed chemo preventive effects against DMBA and croton oil-induced skin cancer in mice as a result of its antioxidant property [31]. In addition to that, Kamepferol showed potential activity in suppression UV radiation-induced skin cancer by targeting certain family of protein kinase which responsible for down regulation the MAPK cascade that activated by solar light. [32]. Quercetin also plays a role in inhibition the growth of papilloma induced by specific initiator and promoter on skin mice tissue by exerting strong anti-oxidant effects [33].

\section{CONCLUSION}

Dried aerial parts of Iraqi Artemisia dracunculus contain many bioactive constituents like glycosides, volatile oils, saponnin, alkaloids, terpenoids, tannin, phenolic compounds and flavonoids. Quercetin, kampferol, and rutin are the main flavonoids present in the Artemisia dracunculus that cultivated in the north of Iraq. In addition to that, the research demonstrates that the methanolic extract of dried parts of Iraqi Artemisia dracunculus has a chemopreventive effect against 7,12-dimethylbenzeanthracine-induced skin cancer. This anti-cancer effect may be attributed to those three flavonoid compounds.

\section{ACKNOWLEDGMENT}

I express my deepest thanks to Mr. Ahmed S. Mahmood (M. Sc Pharmacology) at College of medicine/Al Mustansiriyia for his assistance in doing the animal study. My great appreciation is also 
sent to Dr. ThukaaZ. Abdul-Jalil and Dr. Dhuha Al-Shammaa at College of pharmacy/University of Baghdad for their technical assistance in my research. Finally, I would like to thanks, Dr. Basim Shuhab Ahmed (PhD Pathology) at the College of medicine/Al Mustansiriyia for his effort in the pathological examination.

\section{CONFLICT OF INTERESTS}

Declared none

\section{REFERENCES}

1. Newman DJ, Cragg GM, Snader KM. The influence of natural products upon drug discovery. Nat Prod Res 2000;17:215-34.

2. Obolskiy D, Pischel I, Feistel B, Glotov N, Heinrich M. Artemisia dracunculus L. (tarragon): a critical review of its traditional 2 use, chemical composition, pharmacology, and safety. J Agric Food Chem 2011;59:11367-84.

3. Aglarova AM, Zilfikarov IN, Severtseva OV. Biological characteristics and useful properties of tarragon (Artemisia dracunculus L.). Pharm Chem J 2008;42:81-6.

4. Uhl SR, Strauss S. Handbook of Spices, Seasonings and Flavorings. Technomic Publishing: Lancaster PA; 2000. p. 170-1.

5. Mamedov N, Grdner Z, Craker LE. Medicinal plants used in Central Asia for the treatment of selected skin conditions. J Herbs Spices Med Plants 2004;11:191-222.

6. Alakbarov FU. Medicinal plants used in medieval Azerbaijan phytotherapy. J Herbal Pharmacother 2001;3:35-49.

7. Ribnicky DM, Kuhn P, Poulev A, Roopchand DE., Oren A, Cefalu WT, et al. Artemisia dracunculus L. polyphenols complexed to soy protein show enhanced bioavailability and hypoglycemic activity in C57BL/6 mice. Nutrition 2014;30 Suppl 7-8:54-510.

8. Kirk-Ballard H, Wang ZQ, Acharya P, Zhang XH, YU Yongmei, Klory Gail, et al. An Extract of Artemisia dracunculus L. Inhibits ubiquitin-proteasome activity and preserves skeletal muscle mass in a murine model of diabetes. PLoS One 2013;8:e57112.

9. Firestone GL, Sundar SN. Anticancer activities of artemisinin and its bioactive derivatives. Expert Rev Mol Med 2009;30:11-32.

10. Joshi UJ, Gadge AS, D`mello P, Sinha R, Srivastava S, Govil G. Anti-inflammatory, the antioxidant and anticancer activity of quercetin and its analogues. Int J Res Pharm Biomed Sci 2011;2:1757-66.

11. Mohana DC, Satish S, Raveesha KA. Antibacterial evaluation of some plant extracts against some human pathogenic bacteria. Adv Biol Res 2008;2:49-55.

12. Abdul-Jalil Thg Z. Phytochemical and antimicrobial study of some flavonoids present in the fruits of two Ammi $L$. species wildly grown in Iraq. M. Sc thesis. Baghdad University; 2009. p. 42-3.

13. Kadhim EJ. Phytochemical investigation and testing the effect of Iraqi Echinopsheterophyllus family Compositae on wound healing. PH. D thesis. Bagdad University; 2013. p. 76-7.

14. Maraie NK, Abdul-Jalil Thg Z, Alhamdany AT, Janabi HA. Phytochemical study of the Iraqi beta vulgeris leaves and its clinical application for the treatment of different dermatological diseases. World J Pharm Pharm Sci 2014;3:5-19.

15. Khadim EJ, Abdul-rassol AA, Awad ZJ. Phytochemical investigation of alkaloids in the Iraqi Echiropsheterophyllus (Compositae). Iraqi J Pharm Sci 2014;23:26-34.

16. Bargah RK. Preliminary test of phytochemical screening of crude ethanolic and aqueous extract of Moringa pterygosperma Gaertu. J Pharmacogn Phytochem 2015;4:7-9.

17. Proestos C, Komaitis M. Analysis of naturally occurring phenolic compounds in aromatic plants by RP-HPLC coupled to diode array detector (DAD) and GC-MS after silylation. Foods 2013;2:90-9.

18. Obistioiu D, Cristina RT, Schmerold I, Chizzola R, Stolze K, Nichita I, et al. Chemical characterization by GC-MS and in vitro activity against Candida albicans of volatile fractions prepared from Artemisia dracunculus, Artemisia abrotanum, Artemisia absinthium and Artemisia vulgaris. Chem Central J 2014;8:2-11.

19. Spencer JPE, Vanzour D, Rendeiro C. Flavonoids and cognition: the molecular mechanisms underlying their behavioral effects. Arch Biochem Biophys 2009;492:1-9.

20. Hussein SA. Phytochemical study of some medicinal compounds presents in Hedera helix L. plant cultivated in Iraq. M Sc. thesis Baghdad University; 2014:20.

21. Javier ER, Ricardo Z, Beatriz S, Mario JS. Antioxidant properties and hyphenated HPLC-PDA-MS profiling of chilean fruits (Mangifera indica L. Cv. piqueño). Molecules 2014;19:438-58.

22. Chaudary G. Inhibition of dimethylbenze (a) anthracene (dmba) or croton oil-induced skin tumorigenesis in Swiss albino mice by Aloe vera treatment. Int J Biol Med Res 2011;2:671-8.

23. Zime-Diawara H, Ganfon H, Gbaguidi F, Yemoa A, Bero J, Jansen 0 , et al. The antimalarial action of aqueous and hydroalcoholic extracts of Artemisia annua L. cultivated in Benin: in vitro and in vivo studies. J Chem Pharm Res 2015;7:817-23.

24. Azuine MA, Bhide SV. Chemopreventive effect of turmeric against stomach and skin tumors induced by chemical carcinogens in swiss mice. Nutr Cancer 1992;17:77.

25. Rodzi R, Cheah YL, Ooi KK, Othman F, Mohtarrudin N, Tohid SF, et al. Chemopreventive potential of methanol extract of Dicranopteris linearis leaf on DMBA/croton oil-induced mouse skin carcinogenesis. Afr J Pharm Pharmacol 2013;7:2484-98.

26. Kshirsagar AD, Mohite R, Agrawal AS, Suralkar UR. Hepatoprotective medicinal plants of Ayurveda-a review. Asian J Pharm Clin Res 2011;4:1-8.

27. Lopes-Lutz D, Alviano DS, Alviano CS, Kolodziejczyk PP. Screening of chemical composition, antimicrobial and antioxidant activities of Artemisia essential oils. Phytochemistry 2008;69:1732-8.

28. Eisenman SW, Poulev A, Struwe L, Raskin I, Ribnicky DM. Qualitative variation of anti-diabetic compounds in different tarragon (Artemisia dracunculus L.) cytotypes. Fitoterapia 2011;82:1062-74.

29. Seyed AE, Nasser VM, Remisa V, Mohammad BO. The anticancer activity of five species of artemisia on hep2 and hepG2 cell Lines. Pharmacologyonline 2009;3:327-39.

30. Alabdallat Nessrin G. In vitro antisickling activity of Artemisia Herba-Alba asso (CHIH) methanolic extract on sickle cell disease. Asian J Pharm Clin Res 2016;9 Suppl 1:109-12.

31. Dixit Savita. Anticancer effect of rutin isolated from the methanolic extract of Triticum aestivum straw in mice. Med Sci 2014;2:153-60.

32. Ke. Yao, Hanyong C, Kangdong L, Alyssa L, Ge Y, Yi Z, et al. Kaempferol targets RSK2 and MSK1 to suppress UV radiationinduced skin cancer. Cancer Prev Res 2014;7:958-67.

33. Ali H, Dixit Savita. Quercetin attenuates the development of 7, 12-dimethyl benz (a) anthracene (DMBA) and croton oilinduced skin cancer in mice. J Biomed Res 2015;29:139-44.

\section{How to cite this article}

- Nabaa Mohammed Ibrahem. Extraction and characterization of iraqi artemisia dracunculus dried aerial parts extract though hplc and gc-ms analysis with evaluation of its antitumor activity against 7,12-dimethylbenze(a)anthracene induced skin cancer in mice. Int J Pharm Pharm Sci 2017;9(5):34-42. 